\title{
Economic Development through Mortgage Loan Distribution in Indonesia
}

\author{
Shapran WITDIYANTO ${ }^{1}$ \\ Ariodillah HIDAYAT2* \\ Mukhlis MUKHLIS ${ }^{3}$ \\ Sri ANDAIYANI
}

\begin{abstract}
The growing population of Indonesia is increasing every year, which also leads to the growing need for people's residences. Of course, this affects the financial sector in terms of mortgage loans. Therefore, this paper is a study of the factors that affect the distribution of mortgage loans in Indonesia. This study uses multiple linear regression with ordinary least square analysis with the variables Residential Property Price Index, Lending Rate Credit, and Gross Domestic Product as the independent variable $(X)$ and distribution of mortgages as the dependent variable (Y). The data used in this study are the quarterly time series from 2009 to 2021. Based on the results, the variables Residential Property Price Index, Lending Rate Credit, and Gross Domestic Product have a significant influence on mortgage loan distribution in Indonesia. So, the hope is that the government and the banks can wisely set Lending Rate Credit based on the Gross Domestic Product level of their territory.
\end{abstract}

KEYWORDS: lending rate, economic growth, Residential Property Price Index, mortgage loan

JEL CLASSIFICATION: E50, E51, E59

\section{INTRODUCTION}

Indonesia is a very large country. The number of Indonesians increases every year. Based on the 2020 census, the population of Indonesia is 268.583 .016 people, an increase of 30.9 million people compared to the population in 2010 (BPS, 2020). The total number of citizens each year increased very rapidly, making the number of housing needs in Indonesia continuously increase every year. Because of that, housing is the most important aspect of human life in Indonesia, because the house is a place for people to live and protect themselves from threats. Houses other than as a place to live are also investment assets for people who have direct links to the financial sector. Banking is still very reliable in society as a source of capital, institutions that serve as a medium of lending have a relatively large dependence, compared to non-bank financial institutions. Some factors affect public housing credit in banking, one of which is external factors as well as factors from within. But in any case, this housing credit becomes something that needs to be considered specifically especially after the events of the 2008 crisis that are more vulnerable to problematic credit mortgage (Avanzini et al., 2020).

According to Rakhmawati (2011) researched factors that affect mortgage loans, resulting in that variable GDP, lending Rate, Inflation has a significant influence and there is a positive

\footnotetext{
${ }^{1}$ Sriwijaya University, Indonesia

2* Corresponding author: ariodillahhidayat@fe.unsri.ac.id

${ }^{3}$ Sriwijaya University, Indonesia

${ }^{4}$ Sriwijaya University, Indonesia
} 
influence on people's home loans. But on the other hand, in fact the increase in inflation and GDP which causes house prices to increase does not discourage people from buying a house, because the house is not only a place to live but for long-term investment, and this further spurs the increase in house prices.

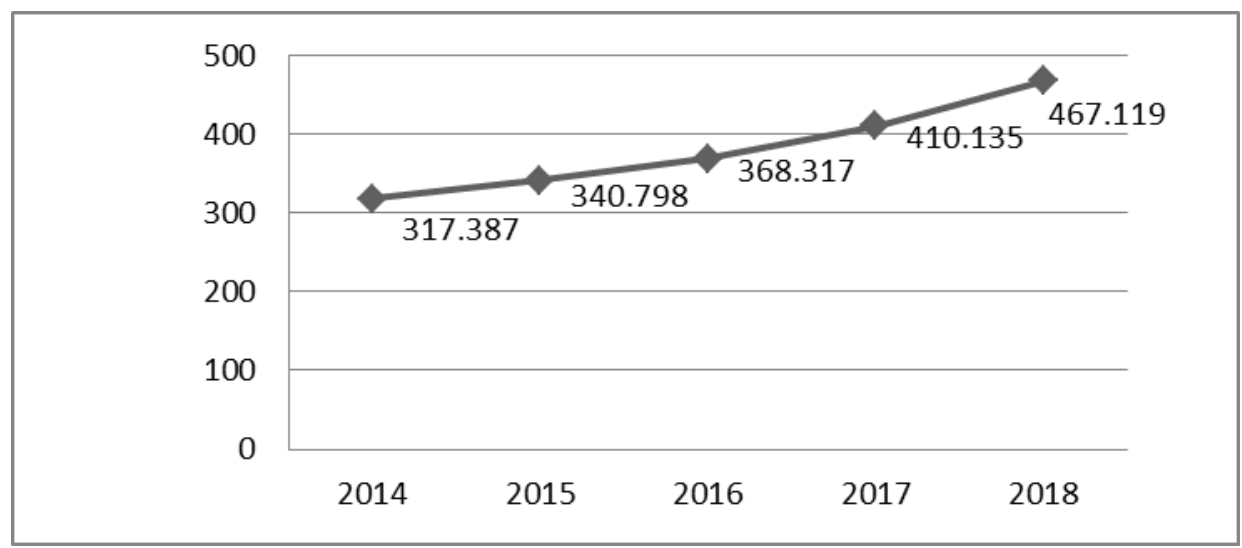

Figure 1. Property loan positions provided by commercial banks. (group of banks and types of utilization)

Source: Bank Indonesia (processed)

This condition causes property loans to always increase after one year. It has become the centre of attention of Indonesian banks to be aware of several things that will make the increase in property asset prices too high and will trigger a bubble from the housing sector considering that the demand for mortgages has always increased from 2014 to 2018 . Analysing the share of property loans will help reduce good risk, especially between loans that are approved by borrowers (Lee \& Bostic, 2020). It should also be noted that there are many institutions that improve housing credit by taking financial advantage when the selling price increases due to the increasing number of enthusiasts, but the quality of credit is decreasing (Simone \& Walks, 2019).

Therefore, banks should reduce the risk of bubbles by controlling lending rates. Thus, the development of mortgages as a community option in buying a house, then housing loans become one of the banking products in terms of home financing that is demand in Indonesia. The equilibrium market situation of the market price of a home property can change due to variable changes beyond the price marked, by the shifting of the demand and supply curve (Sitaningrum, 2006). Because of that, it is very important to analyze the factors that affect mortgage loans in Indonesia. Based on the problems that have been explained in the background, the problem formulation for this study is what factors affect home ownership loans in Indonesia, especially in variable lending rates, GDP and the residential property price index in 2009-2019.

\section{LITERATURE REVIEW}

Several literatures have discussed the factors that affect credit distribution. According to (Rakhmawati, 2011), gross domestic product, interest rates, and inflation have a significant positive effect on people's home loans. This is also supported by research by Khoirudin (2017) and Dewi (2016).

Another study was conducted by Khasanah and Meiranto (2015) using multiple linear regression analysis techniques. The results show that TPF has a positive effect on bank 
lending. In contrast, the study conducted by Njongoro (2013) showed that interest rates had no effect on the growth of mortgage loans.

Furthermore, research conducted by Hillebrand \& Koray (2008) shows that there is a positive relationship between mortgage loans and interest rates. This is contrary to the results of research by Martins and Villanueva (2006), which shows an increase in interest rates will cause a reduction in housing loans.

In this study, the hypothesis is based on from the theoretical framework and the literature review. The interest rate variable is expected to have a negative relationship, where the higher the interest rate will reduce the number of requests for housing loans and vice versa, the lower the interest rate on home ownership loans will increase the number of requests for home ownership loans. The GDP variable is expected to have a positive relationship, where the higher the level of GDP will encourage the number of mortgage requests and vice versa, the lower the demand for housing loans. The Residential Property Price Index is expected to have a negative relationship, where the higher the property price at the Residential Property Price Index will reduce the demand for housing loans and vice versa if the property price at the Residential Property Price Index is low, the lower house prices will encourage the number of credit requests.

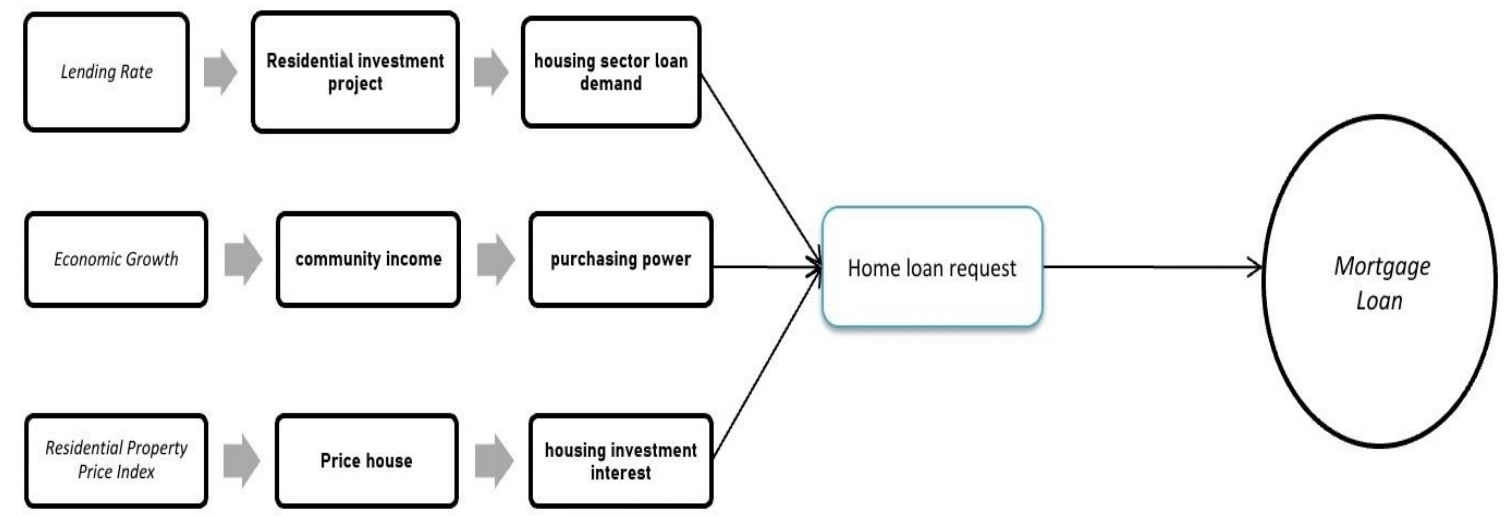

Figure 2. Theoretical framework

Source: authors' own processing

\section{RESEARCH METHOD}

The research entitled "Determinant Analysis of Home Ownership Loan Distribution in Indonesia period 2009-2019". The factors that affect the distribution of housing loans in Indonesia (Y) include the basic lending rate of credit, GDP, the residential property price index during the period 2009-2019 as an independent variable (X). This step begins with the gathering of facts in the market and describes the causal relationship between its variables in order to obtain the actual situation in the mortgage market. (Njongoro, 2013). Secondary data used are times series data from 2009 to 2019.

The basic model used comes from Agbada and Sunny (2015) with the same analytical techniques using GDP to look at its effect on credit distribution in Nigeria. And then the relationship between home mortgage lending and lending rate volatility was conducted by (Hillebrand \& Koray, 2008). Ultimately, researchers took the type of analytical technique used in this study to quantitative analysis using multiple linear regression models from the general model of ordinary least square (OLS) regression. This method of OLS provides 
minimum-variance mean-unbiased estimation when the errors have finite variances. The equation can be written as follows:

$$
\mathrm{Y}=\alpha+\beta \_1 \mathrm{IHPR}+\beta \_2 \mathrm{PDB}+\beta \_3 \text { LENDING RATE CREDIT }+\mathrm{e} \_\mathrm{i} \text {. }
$$

Description:

Y: distribution of mortgage loans

$\beta \_0$ : constant regression

$\beta \_$1: lending rate

$\beta$ 2: GDP

__3: Residential Property Price Index

E_i: Fedgu error

\section{RESULT AND DISCUSSION}

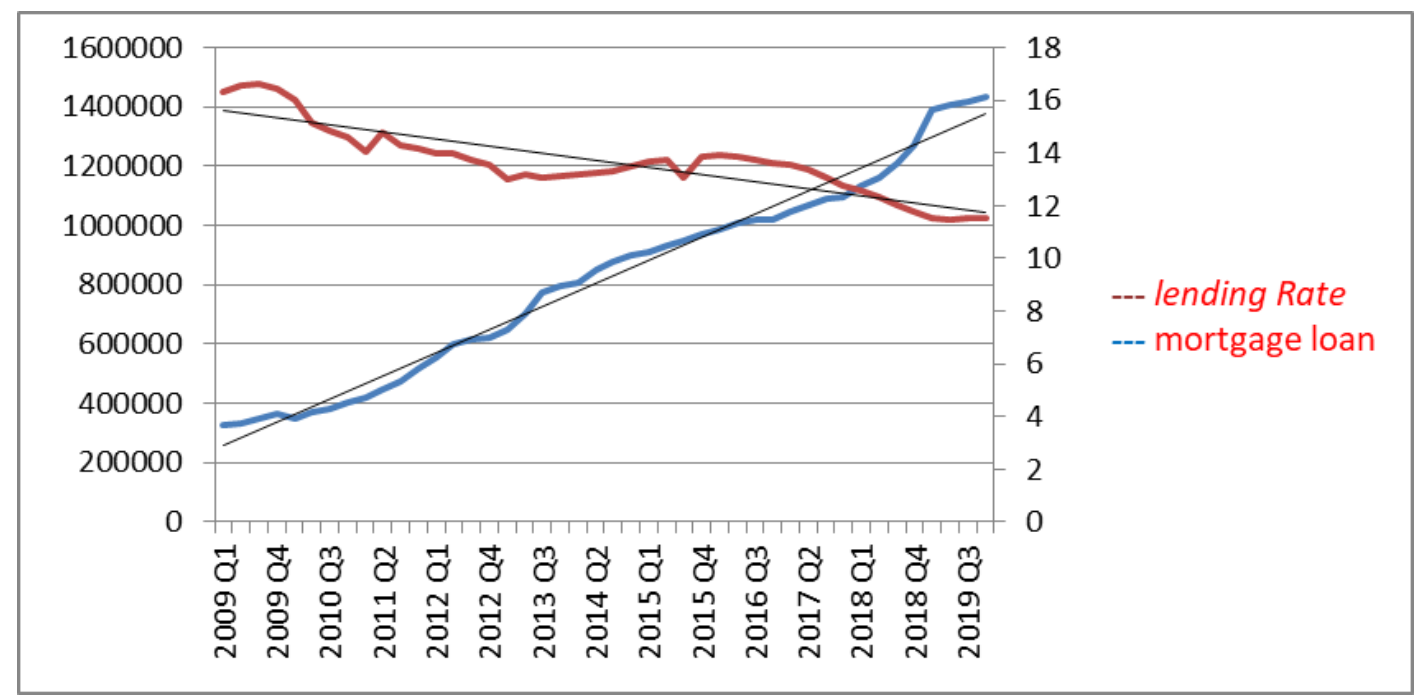

Figure 3. Third-Party funds development and mortgage lending Source: E-views Output

The graph above shows that for independent variables, lending rates with dependent variables of mortgage lending look the opposite graph. This is by the theory of lending rates, where when lending rates fall, it will increase lending by banks. The benefits of a mortgage come with a series of risks, default will hurt many parties, and even cause a financial crisis (Green $\&$ Wachter, 2005). Judging from the chart above, the development of mortgage rates decreased. In 2009, the first quarter mortgage rate stood at 16.33, in 2009 it was known to have the highest number, in the first quarter of 2010 the lending rate reduction indicated continued in line with the decreasing perception of banking economic risk. The average decline to February (since September 2009) reached 56bps.

Credit As the perception of banking economic risk improves, consumption credit lending rates will decrease continuously, making credit growth increase because mortgage lending is still strongly influenced by lending rates. Mortgage values are very sensitive to lending rates and this value relies heavily on rules about the maturity of sales (Green \& Shoven, 1983). Credit growth in the first quarter of 2010 (to 2010) reached (9.4\%) from the end of 2009. The increasing demand for credit is influenced by domestic economic activity that is beginning to recover, accompanied by a continued decline in the lending rate indicated by the spread between the lending rate and the Bank Indonesia rate, which is decreasing. Until the first 
quarter of 2010, the growth of consumer loans in which there is a People's Ownership Loan (KPR) continues to increase in line with the decrease in the lending rate of consumer loans in Indonesia.

In 2016, the third quarter recorded a decrease compared to the previous quarter. In the third quarter, lending rates fell by 15 bps to $13.76 \%$. Year-to-date (ytd), lending rates in the third quarter of 2016 decreased by 60 statistic central bodies (BPS, 2017). The reduction in lending rate occurred in all types of credit, especially consumer credit which decreased by $16 \mathrm{bps}$. For the growth of consumption credit distribution (KPR) is relatively stable because it is supported by high banking capital that makes the distribution of mortgage loans continues to increase by $\mathrm{Rp} 101.848$ trillion body compared to 2015, this being due to lending rates still decreasing.

Credit risk has not also decreased significantly. The easing policy adopted by bank Indonesia has a positive impact on the distribution of mortgage loans in 2017, the easing of the LTV/FTV policy supported by lower lending rates and the still large public demand for housing to drive mortgage growth in Indonesia. This is by the theory that lending rates are negative when lending rates fall and then demand will increase. Mortgage growth in 2017 is on an increasing trend to record $10.5 \%$ higher compared to the growth of the last two years, which is in the range of 7\%. The positive development of mortgages in 2017 was also supported by maintained credit risk, reflected in non-performing loans (NPLs) at a level of $2.6 \%$.

With monetary policy easing through policy rate reduction (BI7DRR) July-October 2019. The credit lending rate decreased in the third quarter of 2019, the lending rate on consumer loans in the third quarter of 2019 was recorded at 11.53, the decrease in the lending rate on consumer loans decreased relatively limited by 3 bps. By loosening the lending policy, the distribution of mortgage loans continues to increase in 2019. Based on the chart above, it appears that the increase in mortgage lending is followed by a decrease in lending rates. By the statement reed (2005) explained the lending rate determines the small amount of credit provided by the bank to finance the mortgage. When lending rates rise, then mortgage loans will below. This is in line with research by Shi et $\mathrm{Al}$ (2014) revealing that higher lending rates should dampen demand for mortgage loans. because higher house prices led to a rise in housing loans which led to high house prices. then it can be concluded that the lending rate of credit negatively affects the disbursement of mortgage loans in Indonesia.

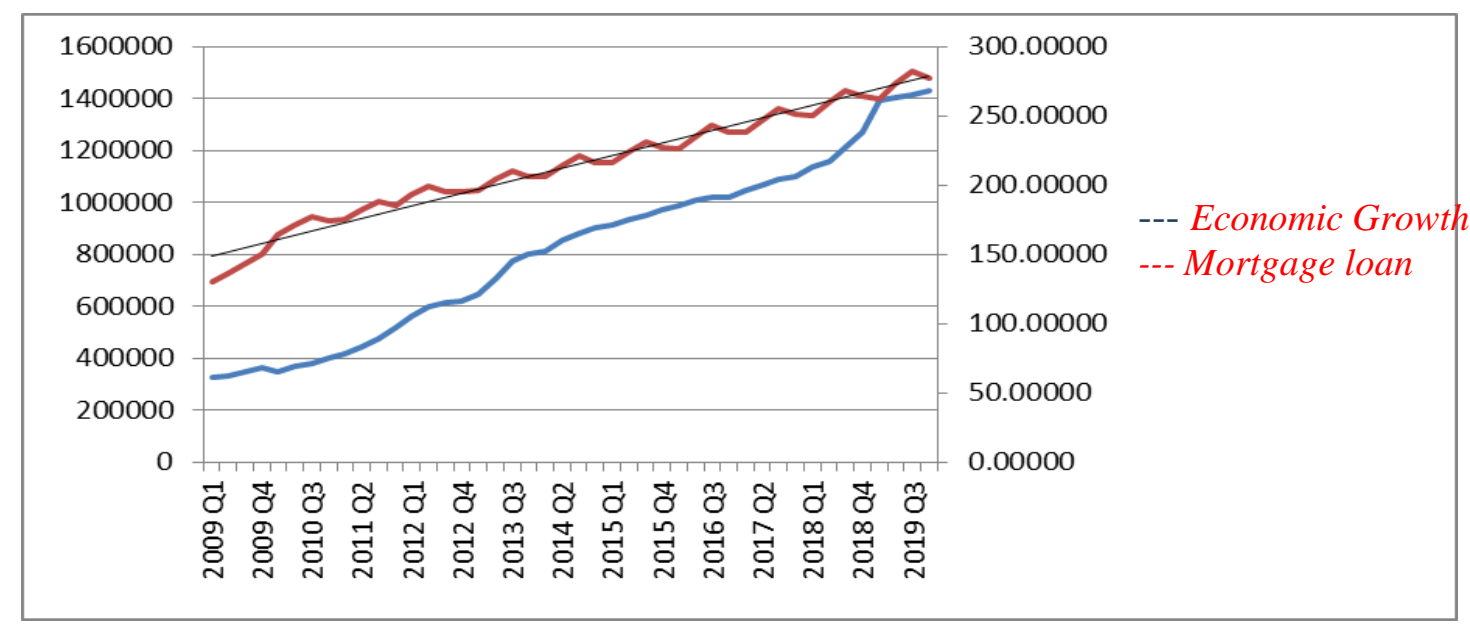

Figure 4. Development of gross domestic product and mortgage lending Source: E-views Output, 2021 
The graph above shows that the development of Gross Domestic Product (GDP) and the level of mortgage lending are increasing. Increase in GDP in the distribution of mortgage loans grows in accordance with the relevance and completeness capacity of mortgage financing (Agbada \& Sunny, 2015). In 2010, the increase in the gross domestic product was inseparable from increasing household consumption, as it contributed $58.6 \%$ to the nominal formation of GDP which reached Rp.164.15533. As lending rates fell in the first quarter of 2010, mortgage lending jumped sharply from a year earlier. The rapid growth of mortgages caused by rising household consumption and falling lending rates led to high lending in 2010. Moreover, the need for homes also tends to increase, according to the data of home needs growth of 800,000 units per year, the supply is only 300,000 per year, the need for homes continues to increase, reaching 5.8 million units in 2010 .

Entering 2015, Indonesia's economic growth is slowed by the continued weakening of the world economy and reduced capital flows to the emerging market, putting pressure on the country's economic growth in 2015. In the second half of 2015, economic growth began to improve driven by rising domestic demand, and in the household sector, consumer confidence encouraged relatively stable and resilient household consumption growth. overall in 2015, experiencing a slowdown from 2014. In 2015, the bank's performance slowed in line with the slowdown in economic growth, but the bank has issued a policy aimed at restraining the pace of credit slowdown, which is easing policy shown to make room for banks to increase credit in the property sector. The public consumption credit slowed by $9.1 \%$ compared to 2014 of $11.5 \%$ of consumer loans mainly from the household sector, mortgage loans (KPR). The decrease in corporate performance also has an impact on the decrease in household income, thus reducing its consumption credit.

Indonesia's economic recovery continued in 2018. The economic growth in 2018 was recorded to increase compared to the previous year's growth of 5.07\%. Economic growth in 2018 is inseparable from the increasing domestic demand. The household consumption growth increased supported by increased levels of community income. Public income remains high driven by low inflation and the positive impact of fiscal stimulus and major activities in 2018.

In 2018, bank Indonesia's policy to increase the distribution of mortgage loans is to loosen the LTV/FTV for mortgage loans. After conducting bank Indonesia policy, the growth of mortgages remained high, during 2018, mortgages increased by $12.7 \%$. The high growth of mortgage credit in support of credit quality remains good. This development, among others, is reflected in the NPL mortgage ratio in all types of stable properties below 5\%. In line with the graph above, the relationship of gross domestic product and the distribution of mortgage loans have a positive relationship. GDP as an indicator of this economy can be used to provide the economic situation of a country, among them, GDP per capita at a constant price shows the value of rill GDP. The increase in GDP shows an increase in income; from the data, it can be seen to the demand for mortgage loans. Irvin Fisher's simple theory of money demand states that demand for money will increase along with the increase in income. 


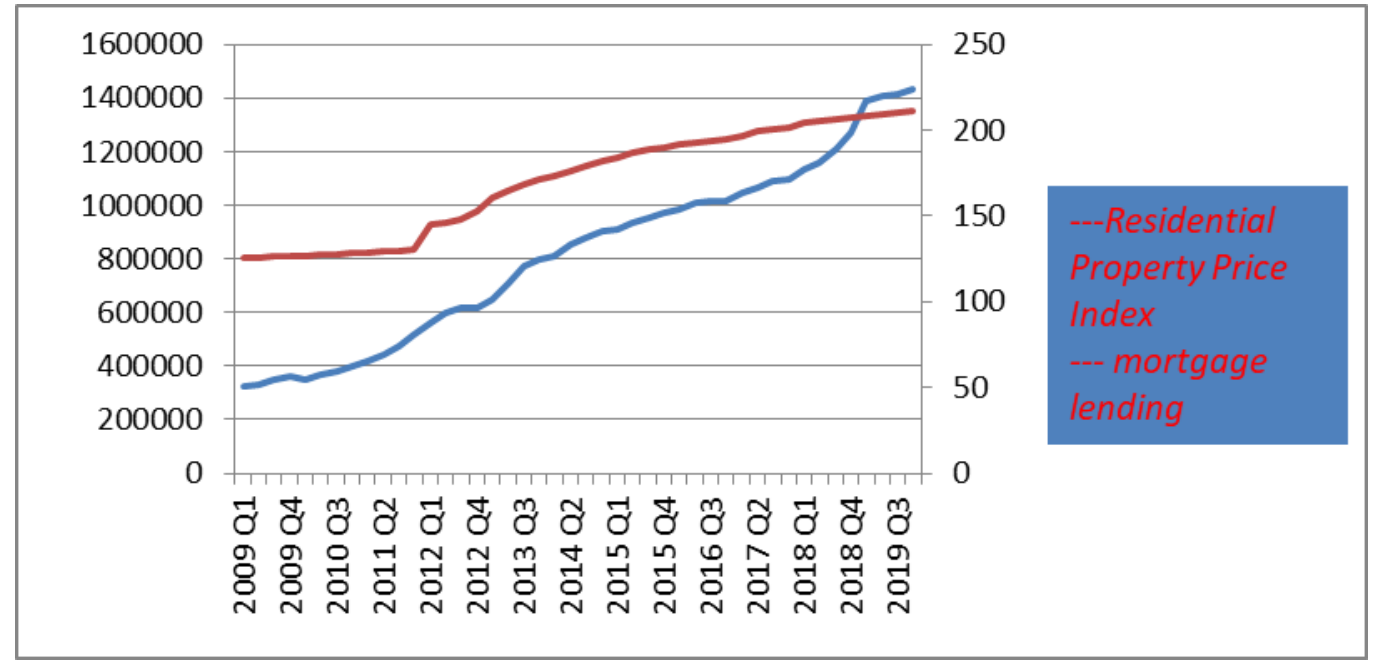

\section{Figure 5. Development of IHPR and mortgage lending}

Source: E-views Output, 2021

As the economy grows, residential property prices change every year. This causes ready-tolive house prices to offer relatively high prices. However, one does not choose a ready-to-live house because there is a way to take this house easily with the option of credit. After all, buying a house is a basic need that must be met. With rising property prices, other prices are rising, including house and land prices, thus buying a home is a profitable investment for the future.

Based on the graph above, shows the development of property prices from year to year increased in line with the distribution of mortgage loans (KPR) increased. In the fourth quarter of 2010, property prices increased from the previous quarter. Based on a survey conducted by Bank Indonesia, this increase is due to soaring prices for building materials, high wages for workers, and high licensing costs. The survey results said that the highest price increase occurred in the Manado region, which is 3.04 percent. In this region, price increases occurred in all types of buildings with the highest increase occurring in small house types $(0.96 \%)$. The distribution of home ownership loans (mortgages) experienced a slowdown from the previous quarter due to the rules of limiting the ratio of credit scores and weakening economic growth. In the first quarter of 2015 a slowdown, in line with the residential property price index increased due to the increase in fuel oil (BBM) will trigger a rise in property prices such as houses, rising property prices will further increase lending in building new properties, because demand for housing is still needed by the community. In the third quarter of 2019, property sector price growth slowed when viewed from IHPR data in the third quarter of 2019 which is still growing limited by $0.50 \%$ compared to $0.41 \%$ in the previous quarter. In the midst of the increase in property prices, limited lending of home ownership in the third quarter increased.

Table 1. Results of interpretation

\begin{tabular}{|c|l|c|c|c|}
\hline & \multicolumn{1}{|c|}{ Variable } & Coefficients & t-statistic & Prob \\
\hline 1 & Constant & 4.742491 & 4.247279 & 0.0002 \\
\hline 2 & Residential Property Price Index & 1.739871 & 16.62763 & 0.0000 \\
\hline 3 & Gross Domestic Product & 0.347459 & 2.762055 & 0.0099 \\
\hline 4 & lending rate & -0.758745 & -3.3742289 & 0.0021 \\
\hline $\mathbf{5}$ & & $\begin{array}{c}\text { R- squared } \\
\mathbf{0 . 9 8 9 1 8 3}\end{array}$ & $\begin{array}{c}\text { Adjusted } \\
\text { R-squared } \\
\mathbf{0 . 9 8 8 0 6 4}\end{array}$ & $\begin{array}{c}\text { F=884.0138 } \\
\text { P=0.000000 }\end{array}$ \\
\hline
\end{tabular}

Source: E-views Output, 2021 
After conducting the classic assumption test stage above, it can be concluded that this model does not experience the problem of classical assumption test either autocorrelation heteroscedasticity or multicollinearity, which means that the results of this modeling can be used as the basis for estimating. Returning to the initial regression result, the result of multiple linear regression can be interpreted as follows:

Based on the above results, the regression coefficient of the equation can be explained as follows:

1. A constant value of $4,742,491$ means that if independent variables do not exist, the value of mortgage lending is $4,742,491$;

2. The coefficient value of b1 of $1,739,871$ means that if the IHPR increases by 1 unit, the distribution of mortgages will increase by $1,739,871$;

3. The coefficient value of b2 of 0.347459 means that if the gross domestic product increases by 1 unit, the distribution of mortgages will increase by 0.347459 ;

4. The coefficient value of $b 4$ of -0.758745 means that if the lending rate increases by 1 unit, then the distribution of mortgages will be reduced by -0.758745 .

Based on the above regression results, we can see the correlation between variable (R) by $99 \%$ and the coefficient of the determinant (R2) which explains that the $0.98 \%$ variation of the mortgage loan distribution (KPR) is explained by independent variables. Together, independent variables have a noticeable (significant) effect on dependent variables with an alpha of $0.05 \%$.

To find out the meaning of the regression coefficient, the $f$ test is conducted, as for the $F$ test in question can be seen in Table 4.8 which shows that the calculated $\mathrm{f}$ value of 884.0138 or greater than the $\mathrm{f}$ table 2.82 with a signification of 0.000 is much smaller than the significant level used in this study, which is $0.05 \%$ or $5 \%$.

Thus, it can be concluded that the above hypothesis testing rejects $\mathrm{H} 0$ and accepts $\mathrm{H} \alpha$. This indicates that IHPR, gross domestic product, and lending rates simultaneously have a significant influence on the distribution of mortgage loans in Indonesia in the period 20092019.

Partially T-Test can be seen below:

1. The Variable Residential Property Price Index (IHPR) has a real effect on the distribution of mortgage loans (KPR) at $\alpha=0.05$. The results show that the higher the property price, the higher the distribution of the mortgage loans. This result is supported by research by Amanda Fatmil (2019), which revealed that IHPR has an effect on the distribution of mortgage loans.

2. The Variable Gross Domestic Product has a real effect on the distribution of mortgage loans (KPR) at $\alpha=0.05$, which means that the increasing GDP will drive the rate of lending of mortgage. This research is supported by Rinda (2015), who states that GDP has a significant impact on the distribution of mortgage loans in Indonesia.

3. The Variable Lending Rate has a real effect and is negatively related to the distribution of mortgage loans (KPR) at $\alpha=0.05$.

\section{CONCLUSION}

This research focused on analyzing residual property price indexes, lending rates, and gross domestic product against the distribution of mortgage loans. It was concluded into three parts. First, the Lending Rate has a significant effect on the distribution of mortgage loans in general. However, if more specifically at the level of young individuals who have relatively 
low incomes do not respond much to changes in lending rates. Second, the Gross Domestic Product (GDP) has a significant effect on the distribution of mortgage loans. The Gross Domestic Product (GDP) is concluded to have a large influence, but expensive funding will be a new problem for society. Last, the Residential Property Price Index has a significant effect on the distribution of mortgage loans. Based on the results all of independent variables have a significant effect on the distribution of mortgage loans.

Researchers advocate for further research to increase the research period to produce better. Furthermore, it is expected that further research will use a different analytical tool than before so that the results obtained are more representative of the actual situation and use other variables to describe the conditions in Indonesia. The residential property price index continues to increase, making it increasingly difficult for people to own a house. Therefore, this study recommends that banks be wiser in setting loan interest rates so that they can benefit all parties. The success of banks in collecting and distributing funds can be seen from the success of banks in reducing operating costs. A good pricing strategy will increase the demand for credit.

\section{ACKNOWLEDGEMENTS}

Special thanks to Sriwijaya University for allowing us to conduct the research and to all those who have helped until this research can be completed.

\section{REFERENCES}

Agbada, A. O., \& Sunny, E.E. (2015). Empirical Analysis of Primary Mortgage Institutions Fundamentals and Gross Domestic Product Increase in Nigeria. Applied Finance and Accounting, 2(1), 89. doi.org/10.11114/afa.v2i1.1257

Amri, M.A. (2019). Faktor-Faktor Yang Mempengaruhi Keputusan Nasabah Bank OCBC NISP Medan Dalam Pemilihan KPR Konvensional Dan Syariah. Universitas Islam Negeri Sumatera Utara.

Avanzini, D., Martínez, J. F., \& Pérez, V. (2020). Assessing mortgage default risk in fullrecourse economies, with an application to the case of Chile. Latin American Journal of Central Banking, 1(1-4), 100009. doi.org/10.1016/j.latcb.2020.100009

BPS. (2020). No Title. Indonesia Dalam Angka 2020. https://www.bps.go.id/publication /2020/04/29/e9011b3155d45d70823c141f/statistik-indonesia-2020.html

Dewi, R.A.P. (2016). Analisis Permintaan Kredit Pemilikan Rumah (Studi Kasus Bank Tabungan Negara). Jurnal Ilmiah Mahasiswa, 4(2).

Green, J., \& Shoven, J.B. (1983). The Effects Of Interest Rates On Mortgage Prepayment. Working paper, DOI 10.3386/w1246.

Green, R.K., \& Wachter, S.M. (2005). The American Mortgage In Historical And International Context. Journal of Economic Perspectives, 19(4), 93-114. https://doi.org/10.1257/089533005775196660

Habiby, T.R. (2012). Analisis Faktor-Faktor Yang Mempengaruhi Nasabah Dalam Meminjam Kredit Kepemilikan Rumah (Kpr) Studi Kasus Di Kota Malang. Jurnal Ilmiah Mahasiswa, 1(2).

Hidayat, G. (2017). Analisis Faktor-Faktor Yang Mempengaruhi Keputusan Permintaan Kpr Pada Bank Syariah Di Kabupaten Sumedang. Coopetition, 8(2), 129.

Hillebrand, E., \& Koray, F. (2008). Interest Rate Volatility and Home Mortgage Loans. Applied Economics, 40(18), 2381-2385. doi.org/10.1080/00036840600949538 
Lailia, A. F. (2019). Influence of Pdrb, Credit Interest Rates and Indices Residential Property Prices (Ihpr) Number of Home Ownership Credit Requests (Kpr) Ready to Live in East Java in 2010-2017. from http://digilib.uinsby.ac.id/32513/

Lee, H., \& Bostic, R. W. (2020). Bank Adaptation To Neighborhood Change: Mortgage Lending And The Community Reinvestment Act. Journal of Urban Economics, 116. doi.org/10.1016/j.jue.2019.103211

Khasanah, U., \& Meiranto, W. (2015). Analisis Pengaruh Faktor Internal Dan Eksternal Terhadap Volume Penyaluran Kredit Perbankan. Diponegoro Journal of Accounting, 4(2), 860-872.

Khoirudin, R. (2017). Determinan Yang Mempengaruhi Jumlah Permintaan Kredit Pemilikan Rumah Di Indonesia. Ekonomikawan: Jurnal Ilmu Ekonomi Dan Studi Pembangunan, 17(2), 100-120.

Martins, N. C., \& Villanueva, E. (2006). The Impact of Mortgage Interest-Rate Subsidies on Household Borrowing. Journal of Public Economics, 90(8-9), 1601-1623. doi.org/10.1016/j.jpubeco.2005.09.007

Mishkin. (2017). Ekonomi Uang, Perbankan, Dan Pasar Uang (sebelas bu).

Njongoro, J. N. (2013). The Effect of Mortagage Interest Rate on the Growth of Mortagage Financing in Kenya. Banking and Finance Journal, 23(9), 57-74.

Putri, G.N.D. (2015). Analisis Faktor-Faktor Yang Mempengaruhi Permintaan Kredit Kepemilikan Rumah (Kpr) Bank Swasta Nasional Di Lampung (Periode 2010: 03-2014: 06). Fakultas Ekonomi dan Bisnis.

Rahayu, B.S. (2014). Pengaruh CAR, NPF, NIM, FDR, dan Pengungkapan CSR terhadap ROA pada perbankan umum syariah di Indonesia tahun 2008-2012. Tesis Pasca Sarjana Magister Manajemen. UNS.

Rakhmawati, D. N. (2011). Analysis of Factors That Affect The Demand for Mortgage Loans at Commercial Banks in Indonesia in 2003-2010.

Sandria, D., Adnan, N., \& Yuliana, S. (2016). Analisis faktor yang mempengaruhi permintaan kredit pemilikan rumah (KPR) di Kota Palembang: Kasus nasabah KPR Bank BTN. Jurnal Ekonomi Pembangunan, 14(2), 54-58.

Setiowati, D.A. (2010). Pelaksanaan Pemberian Kredit Untuk Usaha Kecil Dan Menengah Di Bank Sumsel Cabang Baturaja. Universitas Diponegoro.

Simone, D., \& Walks, A. (2019). Immigration, race, mortgage lending, and the geography of debt in Canada's global cities. Geoforum, 98, 286-299. doi.org/10.1016/j.geoforum. 2017.10.006

Sinulingga, M.Y. (2019). Analisis Faktor-Faktor yang Mempengaruhi Permintaan Kredit Pemilikan Rumah (KPR) pada Bank Pemerintah di Kota Medan. http://repositori.usu.ac.id/handle/123456789/28902

Sudiyatno, B., \& Suroso, J. (2010). Analisis Pengaruh Dana Pihak Ketiga, BOPO, CAR dan LDR terhadap Kinerja Keuangan pada Sektor Perbankan yang Go Public di Bursa Efek Indonesia (BEI)(Periode 2005-2008). Dinamika Keuangan Dan Perbankan, 2(2).

Sitaningrum, I.Y. (2006). Analysis Of Factors That Affect Distribution Of Residential Property Loans In Indonesia 1984-2004.

Zubair, A.M. (2017). Analisis Faktor Yang Mempengaruhi Permintaan Kredit Pemilikan Rumah (KPR) Di Kota Malang (Studi Kasus Pada Bank Tabungan Negara Cabang Malang Tahun 2010-2015). Jurnal Ilmiah Mahasiswa, 5(2). 